\title{
Dietary Treatment of Type I Diabetic Nephropathy with Renal Insufficiency
}

\author{
G. Barsotti, A. Cupisti, E. Morelli, M. Meola, S. Giovannetti \\ Nephrology Unit, Clinica Medica 1, University, Pisa, Italy
}

Diabetic nephropathy is a late complication of insulin-dependent diabetes mellitus (IDDM), which appears in about $25-50 \%$ of patients [ 1$], 20$ or 30 years after the onset of diabetes [2].

Diabetic nephropathy must be regarded as a rapidly progressive nephropathy. Although a strict blood glucose control [3] and an aggressive management of arterial hypertension [4] can slow the progressive fall of glomerular filtration rate, several papers show that the end-stage renal failure is reached 5-7 years after the appearance of dipstick-positive proteinuria, and that the mean decline of glomerular filtration rate ranges from 10 to $25 \mathrm{ml} / \mathrm{min} /$ year $[5,6]$.

In recent years, several uncontrolled trials have demonstrated that an adequate dietary protein $(0.6 \mathrm{~g} / \mathrm{kg} /$ day or less $)$ and phosphorus $(600 \mathrm{mg} /$ day or less) restriction can reduce the rate of progression of renal insufficiency and exert other beneficial effects in patients with chronic renal failure of various etiology [7-9]. Recently, a controlled, prospective, randomized trial on the effect of a $0.6 \mathrm{~g} / \mathrm{kg} /$ day protein intake on the progression of renal insufficiency confirmed these results [10]. More recently, a similar protective effect of low-protein and low-phosphorus diets has been reported also in chronic renal failure due to diabetic nephropathy, by clinical, uncontrolled [11-13] and prospective, controlled, randomized trials [14].

The main aim of the present investigation was to evaluate the longterm effect of two different low-protein, vegetarian diets, supplemented with a mixture of essential amino acids and their ketoanalogues in patients with chronic renal failure due to diabetic nephropathy. 
Table J. The supplemented diets

\begin{tabular}{|c|c|}
\hline \multicolumn{2}{|c|}{ For patients with mild renal failure $\left(C_{C r}>20 \mathrm{~m}\left(/ \mathrm{min} / 1.73 \mathrm{~m}^{2}\right)\right.$} \\
\hline Energy & $30-35 \mathrm{kcal} / \mathrm{kg} / \mathrm{day}$ \\
\hline Proteins & $0.7 \mathrm{~g} / \mathrm{kg} / \mathrm{day}$, only from plant foods \\
\hline Carbohydrates & $62-65 \%$ of total energy supply, mainly from normal pasta and bread \\
\hline Lipids & $25-28 \%$ of total energy supply, only plant origin \\
\hline Cholesterol & negligible \\
\hline Phosphorus & $600 \sim 700 \mathrm{mg} / \mathrm{day}$ \\
\hline \multicolumn{2}{|c|}{ For diabetics with severe renal failure $\left(C_{C_{r}}<20 \mathrm{~m} / \mathrm{min}\right)$} \\
\hline Calories & $30-35 \mathrm{kcal} / \mathrm{kg} / \mathrm{day}$ \\
\hline Proteins & $0.35 \mathrm{~g} / \mathrm{kg} / \mathrm{day}$, from plant foods and EAAs supplements \\
\hline Carbohydrates & $\begin{array}{l}65-70 \% \text { of total energy supply, mainly from nitrogen-free, starch-made } \\
\text { foods }\end{array}$ \\
\hline Lipids & $28-32 \%$ of total energy supply, plant origin only \\
\hline Cholesterol & negligible \\
\hline Phosphorus & $350-400 \mathrm{mg} / \mathrm{day}$ \\
\hline
\end{tabular}

Supplements: EAAs + KAs mixture. $\mathrm{CaCO}_{3}$. Vitamin $\mathrm{B}_{12}$, iron.

\section{Patients and Methods}

We submitted to the dietary treatment 23 insulin-dependent diabetics (16 males and 7 females) aged $24-69$ years (mean 48.5 years). The duration of diabetes was $19.6 \pm 6.3$ years, and the mean duration of diabetic nephropathy $5.9 \pm 1.9$ years. The mean creatinine clearance $\left(C_{C_{r}}\right)$ at the beginning of the study was $24.1 \pm 19.8 \mathrm{ml} / \mathrm{min}$. The prevalence of diabetes complications was: retinopathy $88 \%$, neuropathy $56 \%$, arteriopathy $40 \%$; $36 \%$ of patients had retinopathy and arteriopathy, and $28 \%$ retinopathy, arteriopathy and neuropathy.

We used a $0.3 \mathrm{~g} / \mathrm{kg} /$ day protein diet for patients with severe chronic renal failure. having a $\mathrm{C}_{\mathrm{Cr}_{\mathrm{r}}}$ lower than $20 \mathrm{ml} / \mathrm{min}$, and a $0.7 \mathrm{~g} / \mathrm{kg} /$ day protein for patients with less severe chronic renal failure. In both diets the protein source was from foods of vegetable origin only. The phosphorus supply was approximately $350-400$ and $600-700 \mathrm{mg} / \mathrm{day}$, respectively. The diets were supplemented with a mixture of essential amino acids and ketoanalogues in tablets, as it is reported in table 1.

These diets were defined as supplemented diets (SD). The rate of decline of $\mathrm{C}_{\mathrm{Cr}}$ during the SD period was compared with the rate observed in a previous period on free and uncontrolled diet (UD). The follow-up on UD ranged from 8 to 24 months, and on SD from 8 to 58 months. The rate of decline of $C_{C r}$ on UD was retrospectively evaluated in 18 out of the 23 studied diabetics.

Before and at the end of the SD period. we evaluated: $C_{C_{r}}$ and its rate of decline, mean arterial pressure (MAP), daily urinary protein loss (UPR), serum total protcin (sPR) 


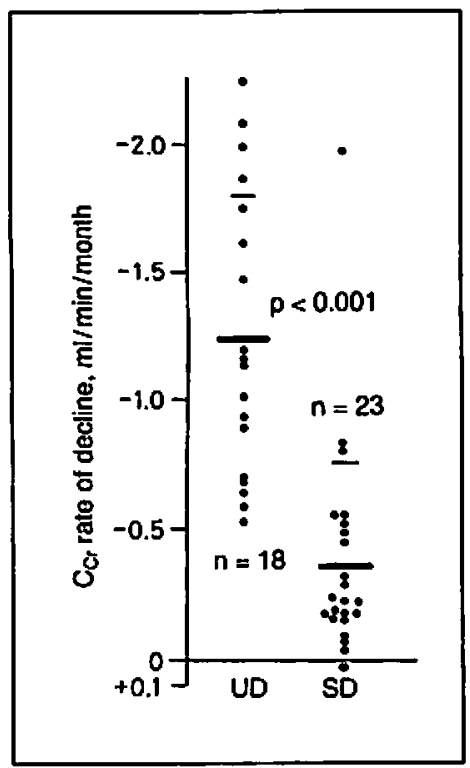

Fig. I. The rate of decline of $\mathrm{C}_{\mathrm{Cr}}$ observed on UD (18 paticnts) and on SD (23 patients) (mean $\pm \mathrm{SD})$.

and serum albumin (sAlb), fasting serum glucose (sG) Jevels, daily insulin requirement (IR), serum calcium ( $(\mathrm{Ca})$, serum inorganic phosphorus $(\mathrm{sPi})$ and parathyroid hormone (middle molecule fragment) (sPTH M-M).

The statistical analysis of the results was performed with a personal computer, by using IBM Epistat software. The results were expressed as mean \pm standard deviation. For the cvaluation of the statistical significance we calculated the Student $t$ test for paired data, and the statistical significance was considered when $p<0.05$.

\section{Resulls}

The $\mathrm{C}_{\mathrm{Cr}}$ rate of decline on UD was $1.21 \pm 0.62 \mathrm{ml} / \mathrm{min} / \mathrm{month}$, significantly different from the mean rate of decline observed on SD $(0.39 \pm$ $0.31 \mathrm{ml} / \mathrm{min} / \mathrm{month}$ ) (fig. I). The MAP on UD was significantly higher than on SD: $116.7 \pm 1.7$ and $113.1 \pm 1.9 \mathrm{~mm} \mathrm{Hg}$, respectively $(p<$ 0.01 ).

UPR significantly decreased on SD, from $4.6 \pm 2.1$ to $2.9 \pm 1.9 \mathrm{~g} /$ day ( $<<0.01$, fig. 2), while sPR increased (fig. 2). sAlb also increased, but not significantly, on SD (fig. 2). 


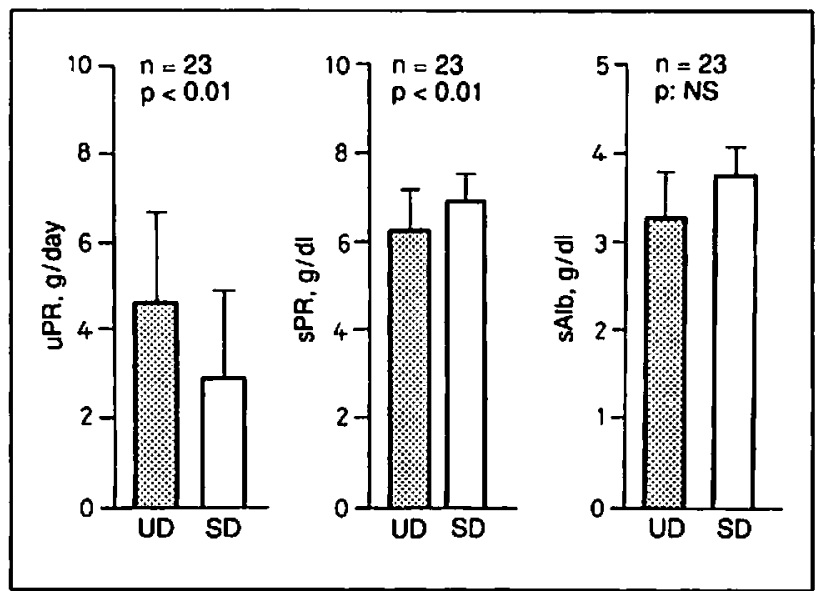

Fig. 2. The behavior of daily uPR, sPR, and sAlb, observed in 23 type I diabetics who changed from UD to SD (mean $\pm S D$ ).

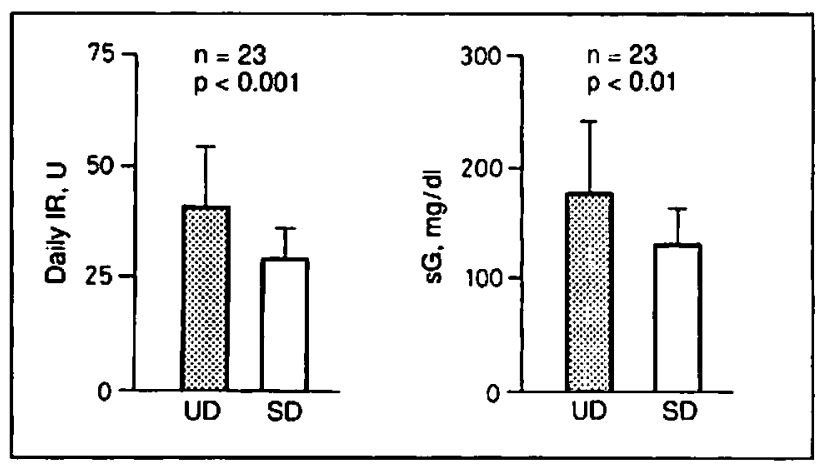

Fig. 3. Daily IR and SG levels on UD and SD (mean \pm SD).

In spite of high carbohydrate intake on SD, the daily IR significantly decreased (from $41.6 \pm 11.8$ to $28.9 \pm 7.6$ units, respectively, $p<0.001$ ) (fig. 3) together with fasting sG levels (from 178.8 \pm 64.4 to $132.6 \pm 31.2$ $\mathrm{mg} / \mathrm{dl}, \mathrm{p}<0.005$ ) (fig. 3).

sPTH M-M decreased from $2.7 \pm 1.6$ to $1.3 \pm 0.7 \mathrm{ng} / \mathrm{ml}$ on $\mathrm{SD}(\mathrm{p}<$ 0.001 , fig. 4). sPi decreased from $5.2 \pm 0.7 \mathrm{mg} / \mathrm{dl}$ on UD to $4.1 \pm 0.5 \mathrm{mg}$ 

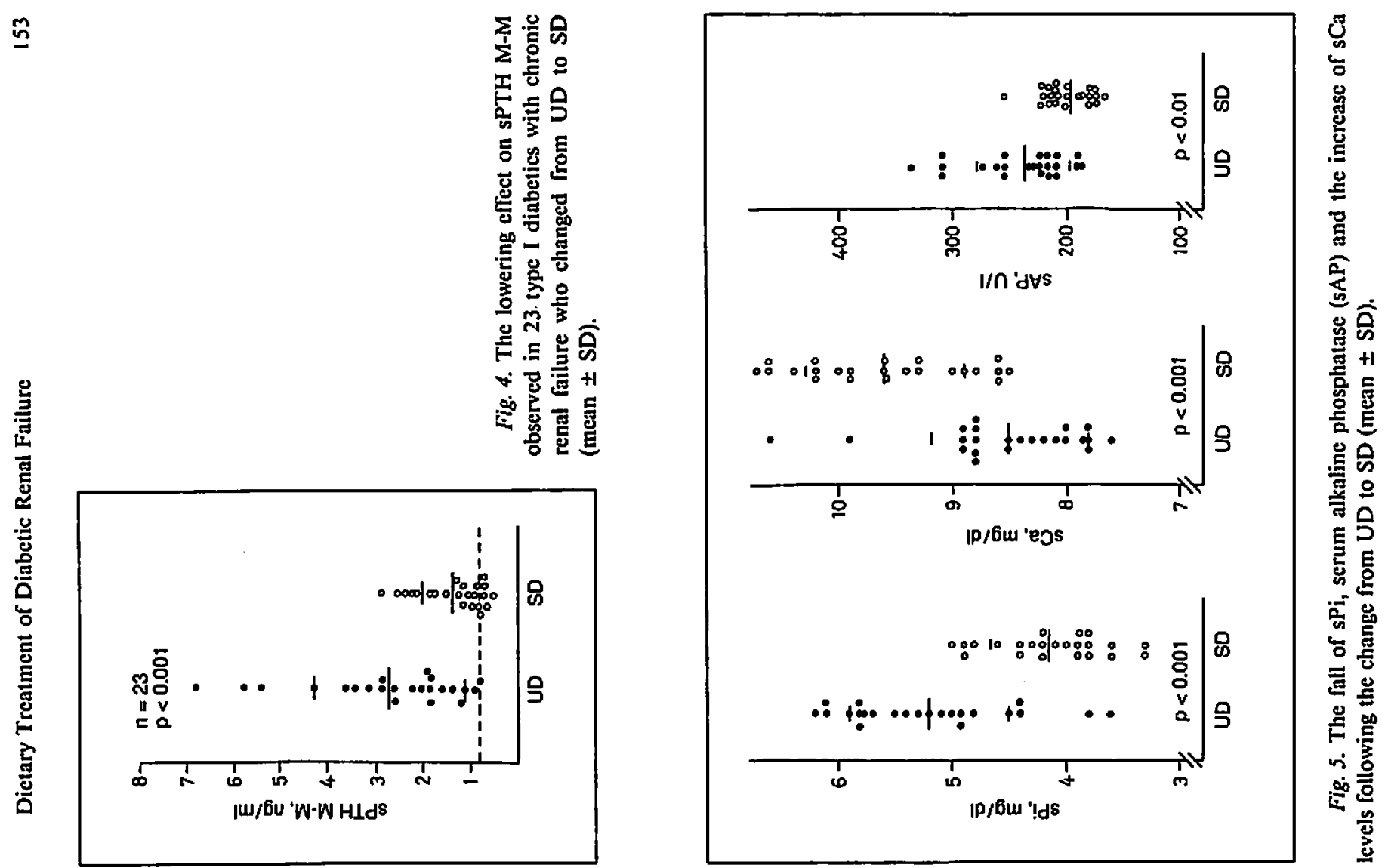
dl on SD ( $p<0.001$; fig. 5). sAP also decreased from $239 \pm 42.3$ to $200 \pm$ $21 \mathrm{U} / \mathrm{l}(\mathrm{p}<0.01$, fig. 5) while sCa increased from $8.5 \pm 0.7$ to $9.6 \pm 0.7$ $\mathrm{mg} / \mathrm{dl}(\mathrm{p}<0.001 ;$ fig. 5$)$.

\section{Discussion}

The lowered rate of decline of $\mathrm{C}_{\mathrm{Cr}}$ observed in our patients shifted from UD to SD may be a consequence of the correction of several factors which may negatively affect the progression of diabetic nephropathy. A significant role is probably played by the decrease of glomerular hypertension [15] and of hyperfiltration in remnant nephrons [16]. The better control of arterial hypertension observed on SD is another important factor for the protection of residual renal function in IDDM with chronic renal failure [17]. Because heavy proteinuria negatively affects the outcome of glomerular diseases $[18,19]$, the decrease of urinary protein loss may be of some importance for the lower rate of decline of $\mathrm{C}_{\mathrm{Cr}_{r}}$ on SD.

The lowering effect of low-protein diets on daily urinary protein loss is far from being clarified, but the hemodynamic changes at the glomerular level and the correction of hyperfiltration surely play an important role $[20,21]$.

The decrease of daily insulin requirement on SD may be partly accounted for by the improvement of insulin sensitivity and glucose tolerance induced by low-protein and low-phosphorus diets [22], and by the correction of secondary hyperparathyroidism [23] which may be easily explained by the fall of $\mathrm{sPi}$ and the increase of $\mathrm{sCa}$ levels due to lowphosphorus intake and to the calcium carbonate supplementation [24].

In conclusion, the dietary restriction of protein and phosphorus of SD can slow down the rate of progression of chronic renal failure in patients with diabetic nephropathy. SD scems to be a safe, effective and inexpensive therapeutic measure and we think it should be recommended early in the course of type I diabetic nephropathy.

\section{Acknowledgements}

This study was supported by grant No. 67/C from the Dipartimento Sicurezza Sociale, Regione Toscana. The authors thank Farma Biagini SpA, Castelvecchio Pascoli, Lucca. for the generous supply of essential amino acids and ketoacids mixture in tablets. 


\section{References}

1 Knowles HC Jr: Magnitude of the renal failure problem in diabetic patients. Kidney Int 1974;6(suppl 1):2-7.

2 Mogensen CE: Diabetes mellitus and the kidney, Kidney Int 1982;21:673-680.

3 Viberti GC, Bilous RW, Mackintosh D, et al: Long-term correction of hyperglycaemia and progression of renal failure in insulin-dependent diabetes. $\mathrm{Br}$ Med $\mathrm{J}$ 1983;286:598-604.

4 Parving HH, Andersen AR, Smidt UM et al: Effect of antihypertensive treatment on kjdney function in diabetic nephropathy. Br Med J 1987;294:1443-1448.

5 Viberti GC, Bilous RW, Mackintosh D, Keen H: Monitoring glomerular function in diabetic nephropathy. Am J Med 1983:74:256-261.

6 Krolewski AS, Warram JH, Rand LI, Kahn CR: Epidemiologic approach to the etiology of type I diabetes mellitus and its complications. N Engl J Med 1987;317: 1390-1396.

7 Maschio G, Oldrizzi L, Tessitore N, et al: Effect of dietary phosphorus and protein restriction on the progression of carly renal failure. Kidney Int 1982;22:371-376.

8 Barsotti G, Morelli E, Giannoni A, et al: Restricted phosphorus and nitrogen intake to slow the progression of chronic renal failure. Kidney Int 1983(suppl 16):S278S284.

9 Mitch WE, Walser M, Steinman TI, et al: The effect of a keto acid-amino acid supplement to a restricted diet on the progression of chronic renal failure. $N$ Engl J Med 1984;311:623-629.

10 Ihle BU, Becker GJ, Withworth JA, et al: The effect of protein restriction of the progression of renal insufficiency. N Engl J Med 1989:331:1773-1780.

11 Evanoff GV, Thompson CS, Brown J, Weinmann EJ: The effect of dietary protein restriction on the progression of diabetic nephropathy. A 12-month follow-up. Arch Intern Med 1987;147(3):492-495.

12 Barsotti G, Ciardella F. Morelli E, et al: Nutritional treatment of renal failure in type 1 diabetic nephrophathy. Clin Nephrol 1988;29:280-287.

13 Walker JD, Bending JJ, Dodds RA, et al: Restriction of dietary protein and progression of renal failure in diabetic nephropathy. Lancet 1989;ii:1411-1414.

14 Zeller K, Wittaker E, Sullivan L, et al: Effect of restricting dietary protein on the progression of renal failure in patients with insulin-dependent diabetes mellitus. $\mathrm{N}$ Engl J Med 1991;324:78-84.

15 Kenner $\mathrm{CH}$, Evan AP, Blomgren P, Aronoff GR, Luft FC: Effect of protein intake on renal function and structure in partially nephrectomized rats. Kidney Int 1985;27: 739-750.

16 Hostetter TH, Olson JL, Rennke HD, et al: Hyperfiltration in remnant nephrons: a potentially adverse response to renal ablation. Am J Physiol 1981;241:F85-F92.

17 Mogensen CE: Long-term antihypertensive treatment inhibits the progression of diabetic nephropathy. Br Med J 1982;i:2-7.

18 Hunt LP, Short DC, Mallick NP: Prognostic indicators in patients presenting with nephrotic syndrome. Kidney Int 1988;34:482-488.

19 Olsen JL, Hostetter TH, Rennke HG, Brenner BM, Venkatachalam MA: Altered glomerular permsclectivity and progressive sclerosis following extreme ablation of renal mass. Kidncy Int 1982;22:112-126. 
20 Gayner R, Neugarten J: Influence of dictary protein content on glomerular hemodynamics and permselectivity in nephrotoxic serum nephritis (abstract). Kidney Int 1990;37:506A.

21 Zatz R, Rentz Dunn B, Meyer TW, et al: Prevention of diabetic glomerulopathy by pharmacological amelioration of glomerular capillary hypertension. J Clin Invest 1986;77:1925-1932.

22 Massry SG: Current status of the role of parathyroid hormone in uremic toxicity; in Amerio A, Coratelli P, Campese VM, Massry SG (eds): Metabolic and Endocrine Disturbances in Renal Diseases. Contrib Nephrol. Basel, Karger, 1985, vol 49, pp I-II.

23 Gin H, Aparicio M, Potaux L, et al: Low protein and low phosphorus diet in patients with chronic renal failure: influence on glucose tolerance and insulin sensitivity. Metabolism 1987;36:1080-1085.

24 Barsotti G, Morelli E, Guiducci A, et al: Reversal of hyperparathyroidism in severe uremics following very low protein, low phosphorus diet. Nephron 1982;30:310 316.

Prof. Giuliano Barsotti, MD, Clinica Medica 1, University, Via Roma 67, I-56100 Pisa (Italy) 